This is an electronic reprint of the original article. This reprint may differ from the original in pagination and typographic detail.

Author(s): Nissi, Riikka

Title: $\quad$ Spelling out consequences : conditional constructions as a means to resist proposals in organisational planning process

Year: $\quad 2016$

Version:

Please cite the original version:

Nissi, R. (2016). Spelling out consequences : conditional constructions as a means to resist proposals in organisational planning process. Discourse Studies, 18(3), 311329. https://doi.org/10.1177/1461445616634556

All material supplied via JYX is protected by copyright and other intellectual property rights, and duplication or sale of all or part of any of the repository collections is not permitted, except that material may be duplicated by you for your research use or educational purposes in electronic or print form. You must obtain permission for any other use. Electronic or print copies may not be offered, whether for sale or otherwise to anyone who is not an authorised user. 


\title{
Spelling out consequences. Conditional constructions as a means to resist proposals in organisational planning process
}

\author{
Abstract \\ Organisational planning processes often materialise as a series of meetings, where the \\ future of the organisation is jointly discussed and negotiated as a part of local decision \\ making sequences. Using conversation and discourse analytical approaches, this article \\ investigates how proposals concerning the future can also be resisted by employing a \\ specific device, a conditional construction (if $X$, then $Y$ ). The data for the study originate \\ from a city organisation, whose customer services are being developed. The results show \\ how the conditional constructions work in two interrelated ways. Firstly, by introducing a \\ problematic hypothetical situation, they outline the undesirable consequences of the \\ proposed idea in real work life. Secondly, by highlighting the experience of the customer, \\ they present the organisation as benefitting from the potential rejection of the idea. The \\ article discusses the implications of the results for the study of proposal and decision \\ making sequences in longitudinal, multisemiotic discursive processes.
}




\section{Keywords}

Conditional constructions, conversation analysis, discourse analysis, hypothetical situation, longitudinal data, meeting interaction, multimodality, organisational planning, proposals, rejection 


\section{Introduction}

Present-day organisational life is distinguished by substantial planning and development work - such as strategic planning - that aims at creating some new concept or a model concerning the future activities of the organisation (Pälli et al., 2009). These kinds of planning and decision making processes typically materialise as a series of meetings and stretch over a number of months or even years, often involving a large amount of personnel. As a matter of fact, prior research in organisation studies has specifically underlined the importance of engaging various employee groups in such processes in order to enhance the quality of the planning underway (Mantere and Vaara, 2008).

Despite their apparent discursive and interactional character, the organisational planning processes have received little attention within the studies on social interaction. In this tradition, there are some previous works investigating longitudinal data and demonstrating, for example, how learning becomes visible through the development of repair practices (Hellermann, 2009) or how institutional tasks are accomplished through the continuity of themes and courses of action across interrelated encounters (e.g. Bercelli et al., 2013; Voutilainen et al. 2011). However, these studies have focused on settings other than 
organisational. Some other studies have, for their part, investigated decision making and organisational planning, concentrating on actions - such as directives - occurring regularly in workplace meeting interaction (e.g. Asmuß and Oshima, 2012; Stevanovic, 2012; Svennevig and Djordjilovic, 2015; see also Bolander and Sandberg, 2013). Nonetheless, they have largely focused on single conversations where the activities at hand are completed then and there.

In this study, my aim is to contribute to the prior research by examining the dynamics of the organisational planning process that realises as an activity of shared future planning across the series of face-to-face meetings. As noted by Boden (1994: 81), meetings are "the essential mechanism through which organisations create and maintain the practical activity of organising". By doing so, they comprise predicting and outlining the forthcoming activities of the organisation, and in terms of social action, this future-oriented talk commonly materialises as proposal sequences (e.g. Stevanovic, 2012, 2013). In proposals, one of the participants nominates a future action and suggests that it will be realised - the action in question is shown to be contingent on the approval of the recipients (Houtkoop, 1987). 
However, not every time the recipients agree with the proposal made. In this article, I will investigate such cases, in other words, cases, where the proposal concerning the future action of the organisation is rejected. More specifically, I will focus on instances, where the recipients resist the proposal implicitly, without verbalising the actual rejection. I will show that they have a specific device for accomplishing this, namely, a conditional construction, which consists of the main clause and a conditional, subordinate, clause. In Finnish, this construction typically realises as jos-niin 'if-then' clauses (if $X$, then $Y$ ), the first one being in the initial position in a turn or a turn-constructional unit and projecting a turn continuation and the latter one following immediately, with no pause or prosodic boundary between the clauses. In this way, the conditional construction establishes a causal relation between two matters: the first clause introduces a condition for the state of affairs disclosed in the latter clause, where they are presented as probable if the condition mentioned in the first clause is actualised. (Laury, 2012; see also VISK $§ 1134-1135,1595$.

Using conversation analytical (e.g. Sidnell and Stivers, 2012) and discourse analytical (e.g. Hepburn and Potter, 2004; Potter, 2011) approaches, I will investigate the design and sequential positioning of the conditional constructions in my data, focusing on the questions of 1) what kinds of matters the two clauses link together and to what end and 2) 
how the overall construction functions to resist the preceding proposal in sequentially organised talk-in-interaction. These questions are closely interrelated and interwoven with the specific features of my data. Firstly, the design of the conditional constructions exposes the way the alternative and competing versions of the future of the organisation are produced and pursued by the participants. Secondly, the evolvement of the longitudinal planning process becomes visible through the creation of these constructions. Moreover, their use brings out the fact that the single meeting encounters are not only sequentially related to one another but also intrinsically intertwined with various written documents. I will demonstrate that the conditional constructions - the way the rejection of the proposal is legitimised and justificated in their topical content - are not readily detectable as a rejection unless examined as a part of a broader, multisemiotic discursive process.

The article has the following structure. Before proceeding to my analysis, I will recap the earlier research on proposals and their rejection and present my data more closely. This is followed by the analytical chapters. In the discussion, I will conclude my findings and reflect their implications for the study of proposal and decision making sequences in lengthy planning processes. 


\section{Proposals and their rejection as social actions}

Proposals can be seen to belong to directives, namely, to social actions that attempt to get the recipient to perform some action (Stevanovic and Svennevig, 2015) either in the immediate interactional context (proximal proposals) or in the more distant future (remote proposals) (Houtkoop, 1987). ${ }^{2}$ Although various kinds of utterances may be treated as proposals, one can also find conventionalised ways to formulate the action of 'proposing'. In Finnish, for example, proposals commonly materialise as an interrogative or a declarative clause with the finite verb in the conditional mood. In the first case, the clause typically includes a modal verb voida 'can' (voisimmeko avata uuden palvelunumeron 'could we open up a new service number'), and in the latter case, the particle jos 'if' (jos avaisimme uuden palvelunumeron 'how about if we opened up a new service number' $)^{2}$ (VISK $§ 1659,1662$.$) However, the proposal may, for instance, be framed as a thought$ (Stevanovic, 2013) or as a quotation or a formulation (Nissi, 2015) in order to modify the way the idea is imposed on the recipient or to present a proposal that does not solely belong to the speaker. Proposals may also be intertwined with embodied action and the material resources of the setting (Asmuß and Oshima, 2012; Nissi, 2015; Pälli and Lehtinen, 2014). 
Although proposals may create different expectations concerning the participation of the recipient, they anyhow endorse joint decision making. As mentioned, in proposals the speaker names a course of future action and suggests that this action will be realised (Houtkoop, 1987), making acceptance - or rejection - of the proposed matter relevant as a next action. However, as noted by Stevanovic (2013) and Stevanovic and Peräkylä (2012), although proposals include a presumption that the upcoming decision involves more than just one person, this ideal is violated by the very act of making a proposal. This is because even if the decision about the plans under discussion will be a joint one, by proposing the speaker already claims for him/herself the right to suggest such plans. In this way, proposals inherently involve the negotiation of the participants' deontic rights, mirroring the negotiation of the participants' epistemic rights for instance in assessments, where the first speaker claims him/herself an epistemic authority concerning the matter under discussion (Heritage and Raymond, 2005; see also Stevanovic and Peräkylä, 2012). Moreover, rejecting or accepting the proposal are not symmetric alternatives for a response, but the first option can be seen to comprise greater deontic claims than the second one. 
All in all, in proposals, the participants orient to two kinds of sets of deontic rights: the right to propose and the right to accept and/or to reject the proposal. These rights comprise further aspects of a deontic status, namely, the socially and institutionally grounded rights of the speaker to carry out a certain action, and a deontic stance, a public display of these rights. (Stevanovic and Peräkylä, 2012.) In this way, the negotiation and distribution of deontic rights may also be intertwined, for example, with the participants' organisational identity, such as a 'leader' and a 'subordinate'.

In terms of rejecting the proposal, Houtkoop (1987) has shown how the rejection is often delayed - relating to general findings on preference organisation (Pomerantz, 1984), she considers the postponing of a response as the core device for rejecting the proposal. Stevanovic (2012) has shed further light on this mechanism by examining how proposals are transferred into joint decisions - she studies in detail what kinds of steps the decision making sequence consists of. According to her, in order to establish a joint decision, the participants have to at first establish an access to the subject matter of the proposal, in other words, they need to share an understanding of what they are talking about. Secondly, they have to express agreement with the proposer's views, and thirdly, to display commitment to the proposed action. In the light of this, the delayed response can be seen as the recipients' 
lack of initiating a further step in the sequence. Thus, Stevanovic (2012) shows how instead of expressing an outright rejection, the recipients choose to resist the proposal less explicitly, by not expressing the approval on the proposed matter. This can be done, for instance, by treating the successful establishment of access to the proposed matter as the core aim of the interaction or by underlining the agreement with the proposer's views without actually displaying commitment to the action in question.

As Figure 1 below shows, the cases examined in this article occur in the place where the recipients are expected to show agreement to the proposal, for instance, by evaluating it in a positive manner (cf. Stevanovic, 2012).

The decision making sequence comprise three steps after the proposal (Stevanovic 2012):

Proposal $>$ Access $>$ Agreement $>$ Commitment

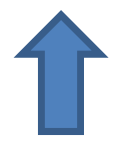

Conditional constructions

Figure 1. The positioning of conditional constructions in the decision making sequence 
However, in my data such positive evaluation does not take place. Instead, as I will later show, the recipients produce a conditional construction that withholds the approval of the proposal by showing why agreeing to the proposed matter would not be a good idea. In this respect, another interesting study is that of Svennevig and Djordjilovic (2015). Defining accounts as actions that warrant a social action by presenting the logic behind it (see Antaki, 1994), they examine how assigning tasks is accounted for in organisational meetings between colleagues. Their study demonstrates the differences in the accounting practices used. Thus, while the leaders often assign tasks to their subordinates without accounting for their entitlement to do so, the subordinates use extensive accounts to legitimise their requests both to their leader and their peers. More importantly, the accounts employed tend to bring the benefits of the proposed action for the successful operation of the company into the spotlight, making this the main resource for legitimating. In this regard, Svennevig and Djordjilovic (2015) connect their findings to some earlier studies showing that the composition of requests may vary according to whether the requested action is seen as a part of some common project (Rossi, 2012) and that requests may generally be accounted 
for by explicating their beneficial effects (Clayman and Heritage, 2014; see also Houtkoop, 1990).

Building on these previous studies, in this article I will set out to investigate how similar legitimising practices may also be employed in a different sequential context, namely, in resisting proposals, yet in a similar kind of a setting, in other words, in organisational meetings where the participants can be seen as being involved in a joint project of running the organisation. I will examine how the conditional constructions are used to unveil the problematic aspects of the proposal, and by doing so, to legitimise the rejection of the proposal without having to verbalise this rejection explicitly. In this respect, there is one further complexity in my data, namely, that the proposal is actually not visible in the preceding sequential context. For the participants, this creates a practical problem: how do you go about resisting a proposal that is not there? I will show how the conditional constructions are specifically employed to circumvent this problem by abstracting the proposal from the turns-of-talk either in the respective meeting or some earlier gathering and even from various written materials related to the planning process. Therefore, I will also demonstrate how the proposal as a 'composite' social action (see Enfield, 2009) 
commences through its responses and through the interplay between interrelated events, written documents and face-to-face interaction.

\section{Data and method}

The data for the study consist of a series of meetings held in a Finnish city organisation and established to develop the customer services of the municipality. ${ }^{3}$ The customer service project was initiated by the Ministry of Finance, who provided written instructions to help to coordinate a similar kind of process nationwide. According to the instructions, the project aims at reorganising the customer services provided by the city in order to create a more transparent and affordable service system. However, the decisions concerning the practical arrangements of the project were left to respective municipalities.

In the target organisation, the customer service project took place over eighteen months and within this time a new model was created for the city's public services including areas such as health care, education and recreation. Most of the meetings were attended by a project

leader who was employed specifically for the project and acted as a chair in the meetings, 
approximately 30 city employees representing different municipal departments, the manager of the city's innovation services, outside consultants as well as various guest speakers.

The project proceeded through various stages. During 1) initial decision making, the city organisation decided to take part in the Ministry's project. This was followed by 2) a preparatory inquiry, which comprised charting the current state of customer services in the city as well as visualising what they could be in the future. The 3) definition stage culminated in a more detailed plan of the new service model, and this plan was put into action during the 4) realisation and the 5) implementation stage. In the first meeting, the project leader explained that the project was about the new customer service model. She also showed a PowerPoint slide and outlined the expected proceeding of the project: the goal was to answer various questions concerning the new model so that this model could then emerge from the discussions of the project group (see Figure 2 below). At this point, the first stage of the project had already been passed. In other words, the project group consisting of the city employees was brought in after the city organisation had already decided to take part in the Ministry's project. 


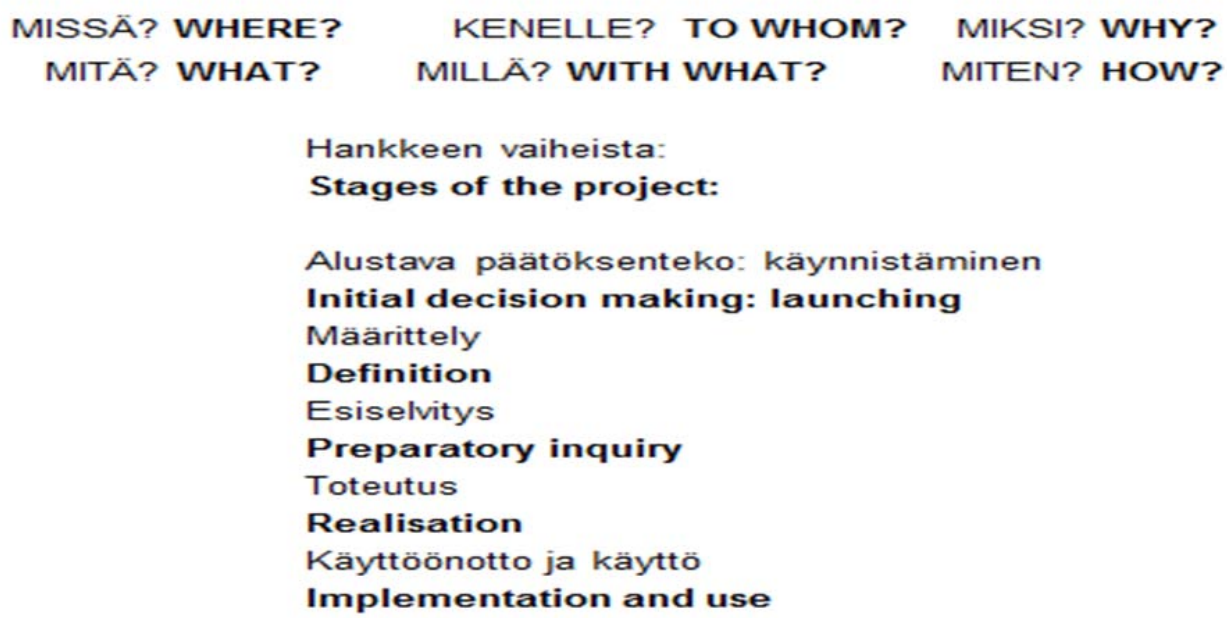

Figure 2. The slide concerning the goal and stages of the project

In this study, the customer service project was followed for first six months, covering the second and the third stages of the project. ${ }^{4}$ In this way, the data collection took place when the new service model was just under planning - the early stages of the project were characterised by the activity of shared future planning concerning the model. Importantly though, the participants did not engage in shared future planning throughout the meetings, but this planning was a clearly identifiable activity in meeting interaction which otherwise consisted of PowerPoint presentations by visiting quests and staff members, informative talks provided by the consultants and so forth. The project meetings - approximately 15 hours - were videotaped by using two cameras and all the written documents connected 
with the meetings were collected. The interactional data was then transcribed according to the conversation analytical notation system.

Going through the data, I noticed that the studied meetings comprise a considerable amount of conditional constructions. Initially, I collected all such constructions in the data set, discovering that they occur in various sequential positions, being often connected to proposal sequences. Because I was especially interested in shared future planning, in this study I excluded the cases where the construction is related to the proposal concerning some immediate action in the meeting (cf. Nissi, 2015) and instead focused on cases where it is related to the proposal having to do with the future customer services. These proposals typically involve the whole organisation and deal with a few competing issues, such as whether or not to open up a new centralised customer service centre and/or a general service number. Here, I further focused on cases where the conditional construction is not a part of the actual proposal, but its response. This sampling produced a collection of 29 cases, which were particularly clustered in places where the participants are engaged in shared future planning. After studying these cases more closely, I found regularities in the way the conditional constructions are composed and employed in meeting interaction, and 
more broadly, in the planning process. These features are investigated in the following analytical sections.

\section{The design of conditional constructions}

In this section, I will at first examine the way the conditional constructions are composed as a combination of the main clause and a conditional clause and how this specific design is used to justify and legitimise the rejection of the proposal. In the cases examined, these two-clause combinations begin with the if ' jos' clause that introduces an idea related to the planned organisational change. More specifically, in it the speaker picks up some detail from the new customer service model and presents it as a condition for the state of affairs disclosed later on in the turn.

This can be seen from the following extracts (1) and (2), which both have the particle jos if' in the initial position in the turn-constructional unit. The extracts come from two different meetings, but in both cases the project members - following the meeting agenda - have been asked to discuss the future options for the city's customer services. As seen below, the 
extracts demonstrate two opposing views as to whether the customer services should be organised under the same premises. Thus, in extract 1, Venla, an employee from the senior and disability services, presents an idea of 'having different sector specific customer service sites' (and consequently no shared, centralised service point). However, in extract 2 , Liisa, an employee from the database administration and telephone services, introduces an idea of 'having a single centralised phone number where one can get customer service' (and consequently no varied sector specific customer service sites). The conditional clause introducing the idea is marked in bold in the extracts.

Extract 1

01Venla: $\rightarrow \quad$-- jos on $\uparrow$ erilä- eri pisteitä (0.4) ${ }^{\circ}(\text { niinku et tai je-) })^{\circ}$ ei ole (.) mitään -- if there are $\uparrow$ diffe-different sites $(0.4)^{\circ}(\text { like that or je-) })^{\circ}$ there isn’t (.) any

$02 \rightarrow$ yhteistä (.) pistettä, (.) nii (1.0) mä pelkään että käy nii että: shared (.) point, (.) then (1.0) I'm afraid that what will happen is tha:t

$03 \rightarrow$ jos se (.) kuntalainen nyt jollekki pisteelle <löytääkin > (0.4) niin hän if the (.) citizen now <happens to find $>$ some service site (0.4) then (s)he 
$04 \quad \rightarrow \quad$ ei $\uparrow \underline{\text { saa }}$ sieltä $(0.4)$ yhen kohtaamisen periaatteella sitä palvelua. won't $\uparrow g \underline{\text { et }}$ the service from there (0.4) with one encounter principle.

Extract 2

01 Liisa: $\rightarrow \quad--$ jos kaupungilla on vaan se yks numero mistä se(n) sais, (0.9) -- if the city has only that one single number where one would get it, (0.9)

$02 \rightarrow$ silloha meiän aika menee (0.4) siihen nii että me ehkä enemmä as you know in that case our time goes (0.4) into having to perhaps

$03 \rightarrow$ jouvutaa auttamaa mut sit ku se kysyyki lisätietoo siitä nii help some more but once (s)he then asks for further information then

$04 \rightarrow$ et pystykkää antaa sit se on kuitenki yhdistettävä se you aren't able to give it so (s) he has to be anyhow forwarded

$05 \quad \rightarrow \quad{ }^{\circ}$ jonnekki eteenpäi ${ }^{\circ}$.

${ }^{\circ}$ somewhere else ${ }^{\circ}$. 
As shown above, the ideas concerning the development of the customer services are typically brought into the conversation in the existential construction (extract 1, line 1; extract 2, line 1), which focuses on the very existence of the presented idea. There is a short break between the conditional clause and the main clause, but the first clause formed with the particle jos 'if' ends in the level intonation. By doing so, it projects both syntactically and prosodically a turn continuation (cf. Laury, 2012), and in what follows, the feasibility of the presented idea is called into question. This is accomplished by combining the idea with a hypothetical situation, which is usually connected to the first clause by the particle niin 'then' (extract 1, line 2) although the particle may also be omitted (see extract 2, line 2; cf. VISK $\S 1134)$. In this way, the described situation is marked as a consequence for the idea disclosed earlier. It may, itself, consist of a further conditional construction (see extract 1, lines 3-4), which is used to delineate the expected course of action within the situation. Importantly, both clauses in the conditional construction are in the present tense ${ }^{5}$ and in the indicative mood, marking the presented courses of action as possible and even probable (VISK $\S 1135) .{ }^{6}$ More specifically, they are introduced as scenarios belonging to the world of an imagination, and by doing so, are used to invite the recipient to reflect the hypothetical world which is shown as parallel to the 'real' world (cf. Peräkylä, 1995). 
Furthermore, although there is some variation in the way the main clause is composed, it anyhow introduces a hypothetical situation, which is seen in a negative light. Thus, in extract 1 , the customer, after a lengthy search for a right service site, finally finds a right place, but is left with a confused customer service experience (lines 2-4). In extract 2, the customer service person working in a centralised service centre uses all the working hours into taking up the service calls, but does not have enough specialised knowledge to answer more specific inquiries - thus having to anyhow forward the customer somewhere else (lines 2-5). Therefore, while the conditional construction suggests a causal relationship between the idea concerning the development of the customer services and the problematic hypothetical situation it also establishes a negative stance towards the idea. In this respect, it accomplishes such stance-taking more efficiently than for example a direct assessment, as it does not only show that something is not a good a good idea, but also lays out reason for why it is not a good idea.

In the light of this, there are a few features that are of particular interest. For a start, the hypothetical scenarios described in the latter clause deal with activities that can be seen to belong to the day-to-day duties of the speaker and are thus based on his/her practical work- 
related knowledge. This, in turn, establishes the suggested courses of action as factual (see Potter, 1996). This is often observable in the way the conditional construction is formulated. In extract 2 above, for instance, the speaker uses a clitic $-h A n$ (line 2) which meaning could be translated as 'as you know', and by doing so, shows to be drawing attention to a selfevident consequence (cf. VISK § 830) available to the speaker and others sharing the same life-world. In other words, the speaker is using his/her epistemic primacy to a certain domain of expert knowledge in order to support his/her deontic rights of rejecting the proposal (see Stevanovic and Peräkylä, 2012).

This 'superior knowing' is particularly noticeable in cases, where the speaker makes his/her professional knowledge visible before producing the conditional construction. In extract 3, for example, the speaker, Jenni, works at the early education services of the city. In her turn, she at first lists all the service options that are currently available in day care services (line 1-9). This list is then used as a basis for producing a conditional construction, in which the speaker introduces an idea of 'having a centralised customer service centre' (lines 10-11) and combines it with a hypothetical situation (lines 11-14).

Extract 3 
01 Jenni: -- (sillo) ku) asiakas tulee ja kysyy päivähoitopaikkaa ni (.) se on (.) -- (when) the customer comes in and asks for a dare care place (.) it is (.)

02 <aikamoinen paketti> (0.4) mitä (.) mitä sille asiakkaalle on tänä päivänä $<$ quite a package> (0.4) what (.) what there is nowadays on $\uparrow$ offer 个tarjolla. (0.3) paitsi se kunnallista lakisääteistä myös näitä for the customer (0.3) not only the municipal legallly binding but also these $\uparrow y k s i t y i s i i$ palveluja .hh (.) joita sitten määrittelee vielä erilaiset palvelusetelin $\uparrow$ private services .hh (.) that are further regulated by different $\uparrow$ conditions myöntämisen $\uparrow$ ehdot, .hh (.) erilaiset eri hoitomuotoihin, (.) for granting service coupons, .hh (.) different for varied day care types, (.) kinder $\uparrow k \underline{\text { artens }}$ child $\uparrow$ minders . hh (.) open early education activities so .hhh (.) so like understanding this whole picture $\uparrow$ plus also 
vielä siihen liittyen kelan maksamat tuet

then the accompanying benefits paid by Kela [social insurance institution]

09

(.) yksityisen hoidon tuet ja .hh (.) ja (.) et ceteraa niin jos $\uparrow$ mietitään (0.3)

(.) benefits for private care and.hh (.) and et cetera so if we $\uparrow$ think (0.3)

$10 \rightarrow$ mietitään sitä että jos meil on tämmönen yhteinen asiakaspalvelupiste ja think that if we have this kind of shared customer service point and

$11 \rightarrow$ sinne henkilö tulee kysyy nii, (0.3) $\uparrow$ mitä hänelle oikeesti vastataan, (.) a person comes in there to enquire then, (0.3) $\uparrow$ what is (s)he really answered, (.)

$12 \rightarrow$ vastataanko $\uparrow$ vaan just siihen kysymykseen mitä hän esimes $\uparrow$ kysyy is (s)he $\uparrow j u s t$ given an answer to that question (s)he is for example $\uparrow$ asking for

$13 \rightarrow$ vai .hh (.) $\uparrow$ osataanko kertoa että (0.4) oletko tietonen et meillä on or.hh (.) are they $\uparrow$ able to tell that (0.4) are you aware that we have

$14 \rightarrow$ myös $\uparrow$ tällasia palvelu(j)a ${ }^{\circ}$ tarjolla ${ }^{\circ}$. 


$$
\text { also } \uparrow \text { these kinds of services on }{ }^{\circ} \text { offer }{ }^{\circ} \text {. }
$$

Here, the hypothetical situation also sheds light on some problematic aspects of the presented idea, namely, that the customer service personnel working in a centralised service centre do not have enough sector-specific knowledge to provide all the relevant information for the inquiring customer (lines 11-14). In constructing the hypothetical situation, the speaker uses interrogatives in order to create alternative consequences and to mark one of them as a more favorable course of action (lines 13-14). This is supported by prior listing (cf. Sanchéz-Ayala, 2003), which again shows that the speaker has an undeniable access to the described events and thus establishes her an epistemic authority (see Heritage, 2013) in outlining the expected chain of affairs.

Moreover, the negativity of the described situation is presented less from the viewpoint of the employee. Instead, the standpoint of the organisation is emphasised, making the presented version of the future scenario very persuasive (see Potter, 1996). This rhetorical construction is particularly accomplished by bringing into the spotlight the customer waiting to get serviced and potentially having a poor customer service experience. In this way, the speaker shows to be considering the position of the organisation, not his/her own the lack of quality in customer service is essentially an organisational problem, because it 
brands the organisation not in a desirable manner. In addition to this, the speakers may explicitly voice the organisational policies in their turns (cf. Svennevig and Djordjilovic, 2015). Looking back on extract 1 , for instance, it can be seen how the speaker refers to the 'one encounter principle' (line 4). By doing so, she contrasts it with the hypothetical situation and thus brings the organisational angle into the spotlight.

All in all, in conditional constructions some idea related to the new customer service model is presented as a condition for the hypothetical situation disclosed later on in the turn. This situation introduces a problematic scenario, which belongs to the professional knowledge domain of the speaker and is usually presented form the viewpoint of the customer. In this way, the conditional construction shows that the complications related to the situation have to do with the quality of the customer care, and removing them - by not applying the presented idea - would benefit the whole organisation.

\section{The use of conditional constructions in the action of resisting}


The previous section demonstrated how conditional constructions are designed to reveal the problematic aspects of the idea related to the development of the customer services. However, it was not shown where these ideas stem from and how the conditional constructions function to resist them in sequentially organised meeting interaction. Therefore, in this section, I will focus on the question of how the conditional constructions are occasioned locally and particularly employed to legitimise the rejection of the proposal in a situation where the proposal itself is not visibly there.

In order to illustrate this, I will show an extract (4) from a meeting, which is a third one in this series of meetings. Prior to this gathering, the project members have been given a three-part task: they should - primarily - describe the current state of the city's customer services, and then think of potential future aims and finally identify risks that might jeopardise the customer service project. The project members have accomplished the task in smaller work groups, and in this meeting they are expected to disclose their group work results to the rest of the project group. At the beginning of extract (4), the project leader (PL) introduces a new topical item - going through the group work - in the meeting interaction and gives the turn to one of the work groups. Henna, who is the secretary of the 
group, begins her answer by addressing the first part of the task. My focus in this extract is on line 5 onwards where the speaker moves on to outlining the potential risks.

Extract 4

01 PL: $\quad$ no $\uparrow$ seuraavaksi sitten (1.1) $\uparrow$ työryhmillä teillä oli tämmönen (0.4)

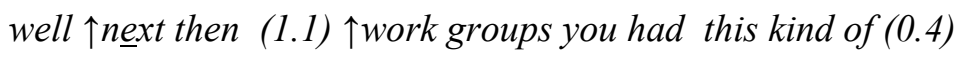

02

välitehtävä?

intermediate task?

((lines omitted: PL explicates the nature of the task and asks group three to perform first))

03 Henna: $\quad$ joo $>$ no tota $<(1.0)(-)$ tota $(0.5)$ joo $($.$) me (.) istahettiin tässä (0.3)$ yes $>$ well uhm< (1.0) (-) well (0.5) yes (.) we (.) had a quick sit down (0.3)

04 pari päivää sitte alas ja --

a couple of days ago and -- 
((lines omitted: Henna addresses the main part of the task))

05 Henna: $\quad$-- <ja $>$ sit käy $\uparrow$ tiin läpi niitä asioita mitä (.) kukin tällä hetkellä -- <and> then we $\uparrow$ went through the things that (.) ourselves at this moment

06 kokee et sieltä omasta palvelusta vois nostaa sellasen $(0.5)$ sellasen tahon feel that could be taken from one's own services to be handled by such (0.5) hoidettavaksi (.) joka ei ole sen kyseisen palvelun <omaa $>$ such party (.) that doesn't represent the $<$ own $>$ expertise of that particular asiantuntijuutta. (1.2) ja: (0.3) kartotettiin vähän niitä rịskejä (.) ja (.) service sector. (1.2) a:nd (0.3) we were charting some of those risks (.) and (.) and $>$ well well $<$ (0.7) our fear at the moment is (.) that the asiakaspalvelu mutkis- $\uparrow$ voi mutkistua. (.) et tuleeko siihen customer service gets comp- $\uparrow$ can get complicated. (.) that is there going to be 
<yksi porras lissää>. (0.6) viekö se (.) vaikeuttaako se (0.7)

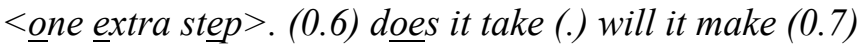

$>$ sanotaan jotai yksittäistä< lipunmyyntiasiaa että $(0.3)$ et

$>$ let's say some single < ticket sales stuff more difficult that (0.3) that

tämmone iha konkreettinen (.) asia tuli et- (.) esiin kun (.) ennakkolippujen this kind of just concrete (.) thing came $u$ - (.) up as (.) selling advance

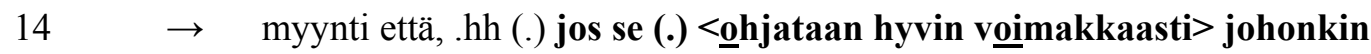
tickets that, .hh if it is (.) < directed very strongly> somewhere

$15 \rightarrow$ muualle kun sinne (.) nykyiseen palveluuun $(0.4)$ nii $\uparrow$ mitäs sitte $\mathrm{ku}$ else than where (.) the services currently are (0.4) then $\uparrow$ what about when

$16 \rightarrow$ ne ennakkoliput loppuu ja se asiakas oppii käymään siellä (.) ja se the advance tickets run out and the customer learns to visit there (.) and the

$17 \rightarrow$ konsertti on vaikka (.) tai: (0.4) teatteriesitys on vaikka (0.7) concert will be for example (.) o:r (0.4) the theatre play will be for example (0.7) 
In her answer, Henna makes visible her orientation to the given task by referring explicitly to its last part, identifying the risks (line 8). This is followed by the risk description, namely, that the customer services might get more complicated (lines 9-10). After nominating the risk, the speaker begins to elaborate it. This is accomplished by producing a paraphrase of the disclosed risk (lines 10-11), followed by a 'real life' example from customer services, in other words, from ticket sales (lines 11-12). The conditional construction is employed as a part of the risk elaboration. Here, the speaker at first introduces an idea of directing the selling of advance tickets somewhere else than where they are currently sold (lines 13-14) and then combines it with a hypothetical situation where such practice causes noticeable complications for the service transaction (lines 15-18).

One can now see how the conditional construction functions as a part of a broader interactional unit. It makes the suggested risk more tangible by unveiling work-related problems that have not been considered or perhaps even known by other meeting participants, but can be authoritatively laid out by people working in this service sector. 
This first-hand knowing is also shown in the way the main clause is designed: the presentation of the hypothetical situation is framed with the expression mitäs sitte $k u$ 'what about when' (line 15), which marks the introduced course of action as inescapable.

Therefore, the conditional construction is embedded in the sequential action of answering the project leader and reporting about the group work. By doing so, the speaker is seemingly aligning with the ongoing activity. However, at the same time, the conditional construction is used to accomplish another action, namely, to resist and to disaffiliate with the idea of centralising the customer services. (Cf. Stivers, 2008.) This can be seen from lines 5-8, where the speaker refers to the discussion that took place in the group meeting and where she already introduces the idea of centralisation. Her indirect quotation creates an expectation that the turn continuation would list what was found as potential areas of centralisation. However, this never happens, as the speaker moves to describing the risks next. In this way, the potential areas are left open, and on the contrary, the turn as a whole suggests that they may not exist at all.

However, as already mentioned, the conditional constructions may not be preceded by a first pair part that would pose an explicit proposal. Similarly here, although Henna's turn 
seems to resist the idea of centralising the services, it is not very obvious where this idea comes from. Interestingly, prior to her turn and to the introductive turn of the project leader, no one has produced such a proposal in this meeting - there is only a presentation by two guest speakers who introduce a new online service system of the city's construction and planning services. However, going further back in time, the project leader has introduced the aims of the customer service project on the PowerPoint slide in the first meeting. Here, centralising the services has already been mentioned as the core target. Furthermore, naming 'one encounter principle" as one of the aims, too, suggests that this centralising could materialise as an actual place where various services could be offered simultaneously (see Figure 3 below). 


\section{Tavoitteita Aims}

- Rakennemuutos: kunnan asiakaspalvelua tuotetaan ja kehitetaăn prosessilăhtōisesti ja palveluita hallinnoidaan keskitetysti.

Structural change: the customer services of the municipality are produced and developed in a process oriented way and services mastered in a centralised manner.

- Asiakaslähtöinen toimintamalli

Customer-oriented model for action

- Yhden kohtaamisen -periaate

One encounter principle

Figure 3. PowerPoint slide presented in the earlier meeting

Similarly, in the instructions provided by the Ministry, centralising the services physically under the same premises has been named as one potential application of the new customer service concept (see Figure 4 below). 


\section{Johdanto}

Asiakaspalvelukeskus-konsepti (ASPA) on kehitetty KuntaIT toimintaan kuuluneessa Oulun, Kuusamon ja Rovaniemen Asiakaspalvelukeskus-projektissa vuosina 2008-2011. Konseptin perusajatuksena on, että kunnan asiakaspalvelua tuotetaan ja kehitetään asiakasja prosessilähtöisesti nykyisen organisaatiolähtöisen toimintatavan sijasta, ja että palveluita hallinnoidaan keskitetysti. ASPA-konseptissa kunnan asiakaspalvelu voidaan järjestää keskitetysti yhdessä asiakaspalvelukeskuksessa tai se voi toimia useassa palvelupisteessä verkostoituneesti.

\section{Introduction}

The Customer Service Centre concept (ASPA) has been developed in the Customer Service Centre project of Oulu, Kuusamo and Rovaniemi [names] related to the activities of KuntaIT [name] during the years 2008-2011. The main aim of the concept is that the customer services of the municipality are produced and developed in a customer and process oriented way instead of current organisation oriented model for action, and that the services are mastered in a centralised manner. In ASPA-concept the customer service of the municipality can be arranged in a centralised way in a single customer service centre or it can function as a network of several service sites.

Figure 4. Extract from the instructions of the Ministry.

Importantly, neither of these written documents proposes establishing a centralised customer service centre explicitly in as much as that they would use a linguistically conventionalised proposal of an interrogative or a declarative clause with the finite verb in the conditional mood (VISK $\S 1659,1662$ ). However, considering the broader textual and interactional context of the remarks discussed above, they can be seen to suggest such a 
thing and by resisting the idea in her turn, Henna also clearly orients to this prior discussion as comprising a proposal concerning the centralised service centre.

Therefore, it could be said that there is a great level of ambiguity both in producing the proposal as well as in resisting it. In terms of social action and its formation, this 'opaqueness' of two different actions can be seen as interrelated. This is because in case of an apparent proposal, one can also take a path of rejecting it, and conversely, by rejecting a proposal in a discernible manner one shows that he/she is treating the preceding turn as a proposal. However, these interactional consequences can be bypassed with the use of a conditional construction. In other words, by employing this device, the speaker can resist the idea without having to commit him/herself openly to the interpretation that anyone ever suggested it, namely, without having to nominate the proposal and the proposer and without having to tie his/her turn to any specific proposal turn.

\section{Conclusions}


This article has investigated the way proposals may be resisted in organisational planning process by means of conditional constructions. Following this, the study focused on examining 1) what kinds of matters the conditional constructions link together and to what end and 2) how the construction is employed in sequential meeting interaction in order to resist the proposal put forward earlier.

As demonstrated in the analysis, the conditional constructions comprise two clauses. The first one begins with the particle jos 'if' and introduces an idea related to the future of the organisation. The second clause is connected to the first one typically by the particle niin 'then' and presents a hypothetical situation, which is shown in the negative light. In the conditional construction, this problematic situation is exposed as a consequence for the idea introduced in the first clause. (Cf. Laury, 2012.) In this way, the conditional construction functions to demonstrate what would be the end result of the proposed idea in case it was carried out in real work life. It does this kind of argumentative work efficiently for two main reasons. Firstly, because the hypothetical situation is situated in the professional knowledge domain of the speaker, it is difficult to challenge - the speaker can authoritatively lay out the undesirable consequences (cf. Heritage, 2013; Potter 1996). Secondly, the conditional construction shows orientation and solidarity towards the 
common good by presenting the organisation as the one benefitting from the potential rejection of the idea (cf. Svennevig and Djordjilovic, 2015). All in all, the conditional constructions allow the participants to express their negative attitudes towards the proposal without taking an overtly rejecting stance (cf. Stevanovic, 2012). In this respect, there is one peculiar feature related to them, namely, that the proposal they are tailored to resist is not visibly there in the preceding turns although - by the very use of the conditional construction - it can be abstracted from the earlier discussion either in written or spoken form.

Interestingly, ambiguity has been previously identified as one of the central characteristics of organisational decision making (Shapira, 1997). From the viewpoint of social interaction, this study can explain some aspects of such equivocation. For a start, there is the question of deontic rights involved in the process. In terms of making a proposal, the leaders of the organisation could be seen as having an inevitable right to propose future courses of action. However, the situation becomes more complicated, if the personnel has been specifically invited to take part in the planning process so that the proposals concerning the future of the organisation would not be seen as coming from top-down, but instead from bottom-up. In such cases, the leaders can hardly put forth an explicit proposal. However, as shown in this 
article, the project management may anyhow have some initial idea and even agreement about the future directions and these views can be discreetly pursued in the meetings.

With respect to rejecting these proposals, the subordinates could, for their part, be seen as having limited rights to do so and hence be similarly using implicit ways to accomplish the action of resisting - particularly since it is not even entirely clear whether something has been proposed or not. Moreover, as demonstrated earlier, the individual employees can also express differing attitudes towards the presented ideas - the conditional constructions can, for example, be employed to resist both the idea of centralising the services as well as having separate service sites. Therefore, by resisting the proposals the subordinates may not only oppose their leaders but also each other, jeopardising the social solidarity among themselves and thus making the planning process particularly delicate.

Secondly, the ambiguity can be seen as connected to the overarching activity type of the planning meetings, which differ from the usual practical-oriented workplace meetings. While in the latter the goal of the gathering is largely to establish decisions about workrelated issues (Stevanovic, 2012), in the first one the institutional task is somewhat different, namely, to form a multifaceted picture of some matter through joint negotiation and 
problematisation (see e.g. Karlsson, 2009). Consequently, the decision concerning the discussed matter is not usually made within the same meeting. This is partly because the decisions may be so substantial in nature that they cannot be reached until all the potential implications have been considered. In the light of this, the participants' conditional constructions can be thought of as having further functions: they hold the decision making sequence there while more information and insight are gathered. It is also this that makes them so convenient device for resisting proposals. Thus, the participants can employ them to voice various concerns related to the planned organisational change while at the same time aligning with the overall activity type and doing exactly what it expected from them.

Finally, things may of course not be as opaque as they first appear. As shown in this paper, organisational planning processes are intrinsically longitudinal and multisemiotic by nature. Because of this, the decision making, for instance, may be difficult for the analyst to trace (Boden, 1994). However, by extending the analysis from single events to broader processes it is possible to see how seemingly disjointed social actions become sequentially organised through the development of activities across interrelated face-to-face encounters and their multisemiotic resources. Given the pervasiveness of such processes in current working life, more research is called for their social and discursive organisation. 


\section{Funding}

This work was supported by the Academy of Finland [grant number 253350].

\section{Notes}

1. Sometimes jos 'if' clauses may also be interpreted as independent depending on their syntactic formatting and the performed action (Laury, 2012).

2. For overlapping of these subclasses see e.g. Stevanovic 2013.

3. This study is a part of a broader research project that investigates how written texts and face-to-face interaction mutually shape each other and form intertextual networks in organisational processes.

4. There is a mistake in the project leader's slides. The 'preparatory inquiry' should be followed by the 'definition'.

5. I have used a future tense in the translation. In Finnish, the present tense can also be used to refer to the future. 
6. Compare different ways to compose a conditional construction and how they present the feasibility of the consequences and the whole scenario (cf. VISK $§ 1135$ )

If we have a new centre, it will be difficult to run (this will be the consequence and the scenario is likely to happen)

If we had a new centre, it would be difficult to run (this will be the consequence, but the scenario itself is rather unlikely)

If we had had a new centre, it would have been difficult to run (this would have been the consequence, but the scenario never happened).

7. See also extract (1) where the speaker refers to this policy.

\section{References}

Antaki C (1994) Explaning and arguing: The social organization of accounts. London: Sage Publications.

Asmuß B and Oshima S (2012). Negotiation of entitlement in proposal sequences. Discourse Studies 14(1): 67-86. 
Bercelli F, Rossano F and Viaro M (2013). Supra-session courses of action in psychotherapy. Journal of Pragmatics 57: 118-137.

Boden D (1994). The business of talk: Organizations in action. Cambridge: Polity Press.

Bolander P and Sandberg J (2013). How employee selection decisions are made in practice. Organization Studies 34(3), 285-311.

Clayman S and Heritage J (2014). Benefactors and beneficiaries: Benefactive status and stance in the management of offers and requests. In: Drew P and Couper-Kuhlen E (eds) Requesting in Social Interaction. Amsterdam/Philadelphia: John Benjamins, pp. 5182.

Enfield N J (2009). The anatomy of meaning: Speech, gesture, and composite utterances. Cambridge: Cambridge University Press. 
Hellermann J (2009). Looking for evidence of language learning in practices of repair: A case study of self-initiated self-repair by an adult learner of English. Scandinavian Journal of Educational Research 53(2), 113-132.

Hepburn A and Potter J (2004). Discourse analytic practice. In: Seale C, Gobo G, Gubrium J F and Silverman D (eds) Qualitative research practice. London: Sage, pp. 180-196.

Heritage J (2013). Action formation and its epistemic (and other) backgrounds. Discourse Studies 15: 55-578.

Houtkoop H (1987). Establishing agreement: An analysis of proposal acceptance sequences. Dordrecht and Providence, RI: Foris Publications.

Houtkoop H (1990). Accounting for proposals. Journal of Pragmatics 14(1): 111-124

Karlsson, A M (2009). Fixing meaning: On the semiotic and interactional role of written texts in a risk analysis meeting. Text \& Talk 29(4), 415-438. 
Laury R (2012). Syntactically non-integrated Finnish Jos 'if' -conditional clauses as directives. Discourse Processes 49(3/4): 213-242.

Mantere S and Vaara E (2008). On the problem of participation in strategy: A critical discursive perspective. Organization Science 19(2), 341-358.

Nissi R (2015). From entry proposals to a joint statement: Practices of shared text production in multiparty meeting interaction. Journal of Pragmatics 79: 1-21.

Pomerantz A (1984) Agreeing and disagreeing with assessments: Some features of preferred/dispreferred turn shapes. In: Atkinson JM and Heritage J (eds) Structures of Social Action: Studies in Conversation Analysis. Cambridge: Cambridge University Press, pp. $57-101$.

Peräkylä A (1995). AIDS counselling: Institutional interaction and clinical practice. Cambridge: Cambridge University Press. 
Potter J (1996). Representing reality: Discourse, rhetoric and social construction. London: Sage.

Potter J (2011). Discursive psychology and the study of naturally occurring talk. In: Silverman D (ed) Qualitative research: Issues of theory, method and practice. London: Sage, pp. 187-207.

Pälli P and Lehtinen E (2014). Making objectives common in performance appraisal interviews. Language \& Communication 39: 92-108.

Pälli P, Vaara E and Sorsa V (2009). Strategy as text and discursive practice: A genrebased approach to strategizing in city administration. Discourse \& Communication 3(3): 303-318.

Rossi G (2012). Bilateral and unilateral requests: The use of imperatives and Mi X? interrogatives in Italian. Discourse Processes 49(5): 426-458. 
Sanchéz-Ayala I (2003). Constructions as resources for interaction: lists in English and Spanish conversation. Discourse Studies 5(3): 323-349.

Shapira Z (1997). Introduction and overview. In: Shapira Z (ed) Organizational decision making. Cambridge: Cambridge University Press, pp. 3-8

Sidnell J and Stivers T (eds) (2012). The handbook of conversation analysis. Boston: Wiley-Blackwell.

Stevanovic M (2012). Establishing joint decisions in a dyad. Discourse Studies 14(6): 779803.

Stevanovic M (2013). Constructing a proposal as a thought: A way to manage problems in the initiation of joint decision-making in Finnish workplace interaction. Pragmatics 23(3): 519-544. 
Stevanovic Melisa and Peräkylä A (2012). Deontic authority in interaction: The right to announce, propose and decide. Research on Language and Social Interaction 45(3): 297321.

Stevanovic M and Svennevig J (2015). Introduction: Epistemics and deontics in conversational directives. Journal of Pragmatics 78: 1-6.

Svennevig J and Djordjilovic O (2015). Accounting for the right to assign a task in meeting interaction. Journal of Pragmatics 78: 98-111.

Stivers T (2008). Stance, alignment and affiliation during storytelling: When nodding is a token of affiliation. Research on Language and Social Interaction 41(1): 31-57.

VISK = Hakulinen A, Vilkuna M, Korhonen R, Koivist V, Heinonen T R and Alho I (2004). Iso suomen kielioppi [A Comprehensive Finnish Grammar]. Helsinki: Finnish Literature Society. Electronic version: http://scripta.kotus.fi/visk URN:ISBN:978-9525446-35-7. 
Voutilainen Liisa, Peräkylä A and Ruusuvuori J (2011). Therapeutic change in interaction:

Conversation analysis of a transforming sequence. Psychotherapy Research 21(3): 348-365.

\section{Appendix. Transcription conventions}

$\begin{array}{ll}\cdot & \text { Falling intonation } \\ ? & \text { Level intonation } \\ \uparrow & \text { Rising intonation } \\ \text { word } & \text { Rise in pitch } \\ >\text { word }< & \text { Emphasis } \\ <\text { word }> & \text { Faster pace than surrounding talk } \\ \text { ?word } & \text { Slower pace than surrounding talk } \\ \text { wo:rd } & \text { Quiet talk } \\ \text { wo- } & \text { Lengthening of the sound } \\ \text {.hh } & \text { Word cut off } \\ \text { [ } & \text { Inbreath }\end{array}$


Pause in seconds

(.)

Micro pause (less than 0.2 seconds)

(word)

Item in doubt

$(-)$

Talk not heard by transcriber

((word))

Transcriber's remarks

\section{Author biography}

Riikka Nissi is a postdoctoral researcher at the University of Jyväskylä, Finland. Her research interests include institutional and professional interaction and discourse. She has conducted research on religious and organisational settings. During this study, she worked as a postdoctoral researcher at the University of Vaasa, Finland, where she examined the networks of written texts and face-to-face encounters in organisations. 